\title{
LATIHAN KEGEL UNTUK MENGOPTIMALKAN KUALITAS HIDUP LANSIA DENGAN INKONTINENSIA URINE DI AREA KERJA PUSKESMAS PARONPONG BANDUNG BARAT
}

\author{
KEGEL EXERCISE TO OPTIMIZE QUALITY OF LIFE OF ELDERLY WITH URINARY \\ INCONTINENCE IN PARONGPONG'S COMMUNITY HEALTH CENTRE WEST \\ BANDUNG
}

\author{
Idauli Simbolon', Debilly Yuan Boyoh² \\ ${ }^{1}$ Fakultas IImu Keperawatan, Universitas Advent Indonesia \\ ${ }^{2}$ Fakultas IImu Keperawatan, Universitas Advent Indonesia \\ E-mail: idauli.simbolon@unai.edu
}

\begin{abstract}
ABSTRAK
Pendahuluan: Inkontinensia Urin (IU) adalah bocornya urin tanpa dapat dikontrol dan sering terjadi pada wanita. Prevalensi meningkat dengan bertambahnya usia. Dampaknya mempengaruhi dimensi fisik, psikologi, sosial ekonomi termasuk kualitas hidup. Tujuan: Penelitian ini bertujuan untuk mengidentifikasi keefektifan latihan Kegel dalam menurunkan frekwensi inkontinensia, jumlah urin yang bocor, dampak negatif dari IU dan kualitas hidup. Metode: quasi experiment digunakan dengan satu grup pre dan post-test dengan populasi wanita lanjut usia yang mengalami IU dengan beberapa kriteria inklusi. Hasil: Hasil penelitian menunjukkan bahwa frekwensi inkontinensia, dan jumlah urin yang bocor berkurang dengan $p<0.05$. Dampak negatif terhadap kegiatan di luar rumah, latihan dan olahraga, hubungan dengan suami, kegiatan seks, berganti pakaian dan perasaan bau menurun secara signifikan $(p<.05)$, namun tidak berdampak terhadap kegiatan di dalam rumah, kualitas tidur dan harga diri ( $p>.05)$. Hasil menunjukkan dampak positif terhadap peningkkatan kualitas hidup dengan nilai $p<.05$. Diskusi: Latihan Kegel direkomendasikan untuk mengatasi inkontinensia urin pada wanita lansia.
\end{abstract}

Kata kunci: Lansia, Latihan Kegel, Kualitas Hidup, Inkontensia Urine.

\begin{abstract}
Introduction: Urinary incontinence (UI) is common among women and the prevalence becomes higher on elderly. The consequences effects on physical, psychological, socio-economical, and reduces the quality of life. Purpose: To identify the effectiveness of Kegel exercise in reducing frequency of being incontinence, amount of urine leakage, negative impacts, and quality of life. Method: A quasi-experimental using one group before-after design is conducted with the population of elderly women who suffer from UI with several inclusion criterions. Result: The study shown that Kegel exercise effective to reduce frequency of being incontinence, amount of urine leakage ( $p$-value <.05) Negative impact such as outside activity, exercise and sport, relation with husband, sex activities, changing clothes, and feeling being smell are reduced ( $p, .05)$, but no effect on indoor activity, quality of sleep and self-esteem ( $p$ $>0.5$ ). It has positive effect on quality of life ( $p$-value <.05). Discussion: Kegel exercise is recommended among elderly women with urinary Incontinence.
\end{abstract}

Key Words: Elderly, Kegel Exercise, Quality of Life, Urinary Incontinence.
JURNAL

SKOLASTIK KEPERAWATAN

Vol, 3, No. 2 Juli-Desember 2017

ISSN: $2443-0935$ E-ISSN 2443 - 1699 


\section{PENDAHULUAN}

Inkontinensia urin (IU) adalah kondisi dimana seseorang secara tidak sadar mengalami kebocoran urin baik dalam jumlah yang sedikit maupun dalam jumlah yang banyak. Hal ini dapat dialami oleh semua orang tidak terkecuali. Namum umumnya prevalensi meningkat sesuai dengan bertambahnya usia terutama pada wanita.

Beberapa fakta menunjukkan bahwa prevalensi IU lebih tinggi pada wanita dibanding pada kaum pria. Menurut Australian Institute of Health and Welfare (AIHW) prevalensi IU pada wanita lebih tinggi setelah berusia 50 tahun dibandingkan pada pria setelah 80 tahun (AIHW, 2012). Hal ini juga didukung oleh data statistik dari Center for Disease Control (CDC). Lebih dari setengah wanita yang berusia 65 tahun keatas mengalami IU dibandingkan lakilaki hanya seperempat (CDC, 2014). Bukti-bukti ini menetapkan perbandingan Perempuan dan laki-laki yang mengalami IU menjadi 2:1 (Irwin, Kopp, Agatep, Milsom, Abram, 2011; Milsom, Altman, Cartwright, et al, 2013).

Di beberapa negara Eropa, penelitian menunjukkan banyaknya wanita yang mengalami IU. Persentasi yang lebih tinggi adalah Francis 44\%, diikuti oleh UK $42 \%$, Jerman $41 \%$ dan Spanyol 23\%. Sementara untuk laki-laki $16 \%$ di Netherland, $14 \%$ di UK dan 7\% di Francis (Boyle, Robertson, Mazetta, et al, 2014).

IU diklasifikasikan ke dalam beberapa tipe yaitu inkontinensia urgency, stress, mixed, functional, overflow dan mixed. Dari kelima tipe tersebut yang paling sering terjadi pada lansia tidak terkecuali wanita atau pria adalah inkontinensia urgency. Hal ini terjadi akibat ketidakmampuan untuk menundah berkemih. Para lanjut usia mengatakan tidak cukup waktu dari merasakan sensasi berkemih hingga tiba di kloset. Urin yang keluar sedikit namun frekuensinya sering. Inkontinensia lain yang juga sering dialami lansia khususnya wanita adalah inkontinensia stress. Urine keluar tanpa bisa dihindari. Terjadi akibat peningkatan tekanan intra-abdomen saat batuk, bersin, tertawa atau latihan fisik.

Hal ini disebabkan oleh melemahnya otot dasar panggul. Gabungan dari kedua inkontinensia urgency dan stress disebut mixed incontinence. Para lanjut usia juga sering mengalami kombinasi dari kedua inkontinensia ini. Inkontinen functional adalah inkontinensia akibat ketidak mampuan lanjut usia mencapai toilet. Sering diakibatkan oleh demensia, immbobilisasi, gangguan musculoskeletal, faktor lingkungan dan juga akibat depresi. Sementara inkontinensia terakhit adala overflow biasanya lebih banyak terjadi pada pria lanjut usia dibanding wanita. Umumnya terjadi karena sumbatan anatomis seperti pada kasus-kasus hipertropi prostat (McCance, Huether, Brashers, \& Rote, 2010; Nugroho, 2012; Thirugnanasothy, 2010; Urology Fondation, 2016).

Prevalensi diantara kategori-kategori tersebut berbeda-beda. Dalam satu survey yang melibatkan 2765 ditemukan bahwa 90 orang diantaranya mengalami IU. IU stress (4\%), IU Mixed (1.6\%) dan Iu lainnya (1.5\%). Prevalensinya lebih tinggi pada lanjut usia. Sebanya $22.2 \%$ lanut usia, $12 \%$ dewasa dan $6.8 \%$ adalah 
anak-anak (Sumardi, Mochtar, Junizaf, Santoso, Setiati, Nuhoni, et al, 2014).

Di Cina diantara 3058 wanita, prevalensi IU diperkirakan $22.1 \%$, IU Stress (12.9\%) adalah yang paling sering muncul dibandingkan dengan urgency UI (1.7\%) dan IU mixed (7.5\%). Tingkat IU urgency dan mixed meningkat sesuai denngan usia. Jumlah yang paling tinggi dicatat pada partisipan yang berusia di atas 70 tahun. IU Stress paling sering ditemukan pada partisipan yang berusia antara 50 sampai 69 tahun (Ge, Yang, Zhang, 2011).

Berbagai faktor dapat meningkatkan timbulnya IU diantaranya adalah jumlah kelahiran pervagina, trauma pelvis, konstipasi, penyakit kronis seperti diabetes dan riwayat operasi ginekologi dan pelvis. Dijelaskan bahwa melahirkan secara spontan atau per vagina meningkatkan resiko IU. Faktor lain adalah kegemukan. Didalam setiap 5 unit peningkatan Indeks Masssa Tubuh (IMT) dapat meningkatkan resiko IU 20-70\%. Berat badan meningkatkan tekanan pada abdominal, yang dapat melemahkan otot pelvis. Dalam penelitian-penelitian yang sudah dilakukan faktor-faktor lain penyebab IU termasuk infeksi saluran perkemihan bagian bawah, kerusakan kognitif dan dimensia, menopause, gangguan neurologi, kesehatan umum yang buruk, penyakit kronis, gangguan pergerakan dan keterbatasan dalam melakukan kegiatan sehari-hari (AIHW, 2012; Milsom, Altman, Cartwright, et al, 2013; Nojomi, Armin, Rad, 2008; Buckley, Lapitan, 2016; Subak, Richter, Hunskaar, 2009).

Dampak negatif dari IU sangat beragam. Dampak negatif dapat mempengaruhi dimensi kehidupan secara fisik, psikologi, sosisal ekonomi dan kualitas hidup. Dampaknya juga bisa sampai mengakibatkan kecacatan dan kematian.

Secara fisik dampat IU khususnya pada lanjut usia termasuk resiko jatuh sebagai akibat dari seringnya terbangun pada malam hari untuk berkemih. Para lanjut usia cenderung mengalami patah pada leher tulang femur. Seringnya bangun pada malam hari juga menyebabkan kualitas dan jumlah jam tidur lansia berkurang. Sebagai akibatnya lansia sering mengalami keletihan dan pusing. Dampak terhadap fisik yang lain termasuk iritasi kulit akibat basah oleh urin. Hubungan seksual dan keintiman dengan pasangan juga terganggu. Beberapa wanita menjaga jarak dari suami mereka dan mengalami penurunan keinginan berhubungan intim (Sinclair, Ramsay, 2011; Nilson, Lalos, Lalos, 2009; William, 2010; Barber, Visco, Wyman, Fant, Bump, 2002).

IU juga dihubungkan dengan tingkat kecemasan dan depresi. Wanita yang mengalami IU dihubungkan dengan tingkat kecemasan yang tinggi. Penderita mengalami depresi tiga kali lebih tinggi dibanding wanita yang tidak mengalami IU (6.1\%:2.2\%). Lagi pula, IU dapat meningkatkan rasa malu yang menyebabkan harga diri rendah (William, 2010; Meville, Delaney, Newton, Katon, 205; Shaw, 2001). Wanita yang menderita IU malu dan takut bocor di depan umum. Perasaan ini menyebabkan mereka menarik diri dan menghindari bepergian termasuk ke tempat-tempat yang baru. Mereka juga takut jika tidak ada toilet dan terdapat antrian yang panjang (Sinclair, Ramsay, 2011).

IU dinyatakan menjadi beban ekonomi bagi individu dan masyarakat. Menurut CDC (2014) di Amerika Serikat pada tahun 2000, biaya yang dikeluarkan 
untuk masalah inkontinensia adalah \$19.5 millyar. Biaya paling tinggi \$14.2 millyar digunakan untuk mereka yang tinggal dimasyarakat dan $\$ 5.3$ millyar billion untuk yang tinggal di institusi perawatan. Sekitar 50-70\% digunakan untuk membeli alas atau penyerap urin, dan membayar binatu (CDC, 2014).

Sepanjang tahun 2008-2009, pemerintah Australia mengeluarkan uang sebanyak \$31.6 millyar untuk masyarakat yang mengalami IU berat dan permanen. Uang tersebut diprojeksikan untuk membeli diaper, pampers dan kateter. Tujuan dari bantuan dana ini adalah agar penderita IU dapat mempertahankan gaya hidup dan tetap aktif dalam masyarakat (AIHW, 2012).

Secara umum IU mempengaruhi kualitas hidup. Dampak tersebut tergantung dari tingkat keparahan IU, kepribadian dari penderita tersebut dan strategi penanganannya (Sinclair, Ramsay, 2011; Nilson, Lalos, Lalos, 2009; Nygaard, 2010; Charalambous, Trantafylidis, 2009).

Salah satu manajemen IU adalah adalah latihan menguatkan otot dasar panggul menggunakan latihan Kegel. Canadian Foundation of Continence (2016) merekomendasikan latihan Kegel. Kegel merupakan nama penemu latihan Kegel. Dia seorang dokter ahli ginekolog dari universitas Southern California. Pada tahun 1951 dia memperkenalkan latihan otot dasar pelvis kepada 500 wanita yang mengalami IU. Dia meminta para wanita tersebut untuk menekan balon berbentuk kone yang disebut perinometer yang dimasukkan ke dalam vagina wanita tersebut. Wanita tersebut diminta untuk melakukan kontraksi dan relaksasi selama 20 menit, tiga kali sehari dan sebanyak 300 kontraksi. Hasil yang ditemukan adalah $80 \%$ frekwensi IU berkurang (The Canadian Continence Foundation, 2016; Kolcaba, Dowd, 2000). Latihan Kegel juga dimasukkan sebagai intervensi primer mengatasi inkontinensia Urine (Potter dan Perry, 1993).

Latihan Kegel sudah sering diteliti namun masih banyak wanita yang mengalami IU termasuk lanjut usia yang belum terpapar dengan latihan ini. Sehingga peneliti ingin menerapkan latihan ini seraya membuktikan kepada para partisipan keefektifan dari latihan kegel ini. Penelitian ini menjadi penting terutama kepada para partisipan. Saat mereka berpartisipasi di dalam penelitian ini, mereka juga menjadi terlatih dalam melakukan latihan Kegel. Pada akhirnya otot pelvis akan semakin kuat dan diharapkan mengurangi frekwensi IU. Setelah merasakan dampaknya maka para lansia akan berbagi informasi sehingga semakin banyak lansia yang terpapar dengan latihan Kegel.

\section{BAHAN DAN METODE}

Penilitian ini merupakan quasi experiment melalui pendekatan nonrandomized one group pretest and posttest design. Populasinya adala wanita lanjut usia yang mengalami IU dengan penarikan sampel secara purposive melalui beberapa inklusi yaitu, usia 45 tahun keatas, mampu membaca dan menulis, dapat mengerti instruksi dalam bahasa Indonesia, mampu berjalan ke toilet, dan mampu menemukan otot dasar panggung dengan benar.

Sampel penelitian terdiri dari 100 wanita lansia yang memenuhi kriteria inklusi tersebut di atas. Proses pengumpulan data dimulai dengan penjelasan tentang tujuan dan benefit dari penelitian. Setiap 
partisipan diberi kesempatan untuk bertanya. Setelah itu maka dilakukan skrining tentang IU. Ada 4 pertanyaan yang diajukan, apabila partisipan menjawab ya pada salah satu 1 atau lebih pertanyaan skrining maka lansia tersebut didaftarkan sebagai partisipan. Lalu calon partisipan diminta untuk menandatangi surat persetujuan secara volunter untuk mengikuti program latihan Kegel selama 21 hari. Setelah itu partisipan dilatih bagaimana melakukan latihan Kegel sampai setiap partisipan mampu melakukannya dengan benar. Untuk memastikan partisipan menemukan otot yang harus dilatih, maka satu persatu lansia di latih di toilet. Mereka diminta untuk berkemih. Saat berkemih para wanita diminta menahan urin dan melepaskannya untuk beberapa kali. Hanya lanjut usia yang mampu menahan urin yang dilibatkan didalam penelitian ini. Setiap partisipan diberitahu bahwa mereka berhak mengundurkan diri apabila merasa tidak nyaman dan tidak bersedia meneruskan latihan Kegel. Setelah lansia mampu mendapatkan otot yang benar untuk dilatih maka diberikan pertanyaan pretest tentang frekwensi IU, jumlah urin yang bocor, dampak negatif dan kualitas hidup.

Selama 21 hari petugas lapangan mengunjungi partisipan untuk memastikan pelaksanaan latihan Kegel. Setelah 21 hari Maka post-test dilakukan untuk mengetahui frekwensi inkontinensia, jumlah urine yang bocor, dampak negatif dan kualitas hidup. Ukuran yang digunakan pada penelitian ini mencakup frekwensi inkontinensia diukur dengan skala $0=$ tidak pernah, $1=$ sekali seminggu, 2=2-3 kali seminggu, $3=$ sekali sehari, $4=$ beberapakali sehari, $5=$ setiap saat. Jumlah urin yang bocor diukur dengan skala $0=$ tidak ada, $2=$ sedikit, $4=$ sedang, 6= banyak. Dampak negatif menggunakan 9 pertanyaan dengan skala $0=$ tidak ada dampak, $1=$ dampaknya sedikit, $2=$ dampak sedang, $3=$ dampaknya banyak, 4= dampaknya sangat banyak. Kualitas hidup diukur dengan skala $1=$ sangat buruk, $2=$ buruk, $3=$ tidak baik dan tidak buruk, $4=$ baik, dan $4=$ sangat baik. Penelitian dilakukan dari bulan Oktober 2016 Sampai maret 2017. Analisa data diskriptif dan compare mean (paired t-test) dilakukan dengan menggunakan perangkat lunak SPSS.

\section{HASIL}

Seluruh partisipan adalah wanita yang berjumlah 100 orang. Usia mulai dari 4585 tahun dengan usia rata-rata adalah 65 tahun. Semua partisipan berhasil menyelesaikan latihan Kegel selama 21 hari sesuai dengan yang dtetapkan di surat persetujuan. Hasil penelitian ini menggambarkan aspek-aspek yang diukur antara lain pengukuran skrining IU, pengukuran frekwensi inkontinesia, jumlah urine yang bocor, dampak negatif IU dan kualitas hidup sebelum dan sesudah latihan Kegel.

\section{Skrining IU}

Ada 4 pertanyaan yang digunakan sebagai prosedur skrining IU. Jawaban terhadap pertanyaan tersebut adalah ya atau tidak. Wanita yang memiliki jawaban iya paling sedikit satu kali diperhitungkan sebagai penderita IU.

Tabel 1. Data Skrining IU

\begin{tabular}{lcc}
\hline Pertanyaan Skrining & Ya & Tidak \\
\hline $\begin{array}{l}\text { Apakah anda pernah mengalami bocor } \\
\text { tampa sadar? }\end{array}$ & 100 & 0 \\
$\begin{array}{l}\text { Apakah anda pernah mengalami bocor } \\
\text { saat batuk, tertawa, atau alahraga? }\end{array}$ & 60 & 40 \\
$\begin{array}{l}\text { Apakah anda pernah mengalami bocor } \\
\text { sebelum sampai di toilet }\end{array}$ & 30 & 70 \\
$\begin{array}{l}\text { Apakah anda pernah menggunakan } \\
\text { pembalut, tissue atau kain di pakaian }\end{array}$ & 100 & 0 \\
dalam untuk menampung urin & & \\
& &
\end{tabular}


German Network of Quality Development in Nursing (Deutsches Netzwerk für Qualitätsentwicklung in der Pflege) merekomendasikan 4 pertanyaan tersebut sebagai instrumen untuk melakukan skrining IU (Association of Women's Health Obstetric and Neo-natal Nurse. Continence for women, 2000; Zurcher, Saxer, Schwendimann, 2011).

Di dalam tabel-1 dapat dilihat bahwa $100 \%$ patisipan menjawab pernah mengalami bocor urin tanpa sadar. Lebih dari setengah atau $60 \%$ pernah mengalami bocor saat batuk tertawa atau saat berolahraga. Sekitar $30 \%$ lansia mengalami bocor sebelum samapi di toilet. Selanjutnya $100 \%$ mereka pernah meggunakan bahan penyerap untuk menampung urin yang bocor. Masingmasing partisipan memiliki jawaban ya lebih dari satu kali sehinga menurut prosedur skrining IU, $100 \%$ partisipan menderita IU.

Frekwensi Inkontinensia

Tabel 2. mengindikasikan bahwa frekwensi IU menurun setelah mengikuti latihan Kegel. Sebelum latihan rerata urin adalah 1.00 dan sesudah latihan menurun menjadi .21. Perbedaan nilai rata-rata adalah .79 dan nilai $p .000$.

Tabel 2. Nilai Analisis Compare Mean Jumlah Urine yang Bocor

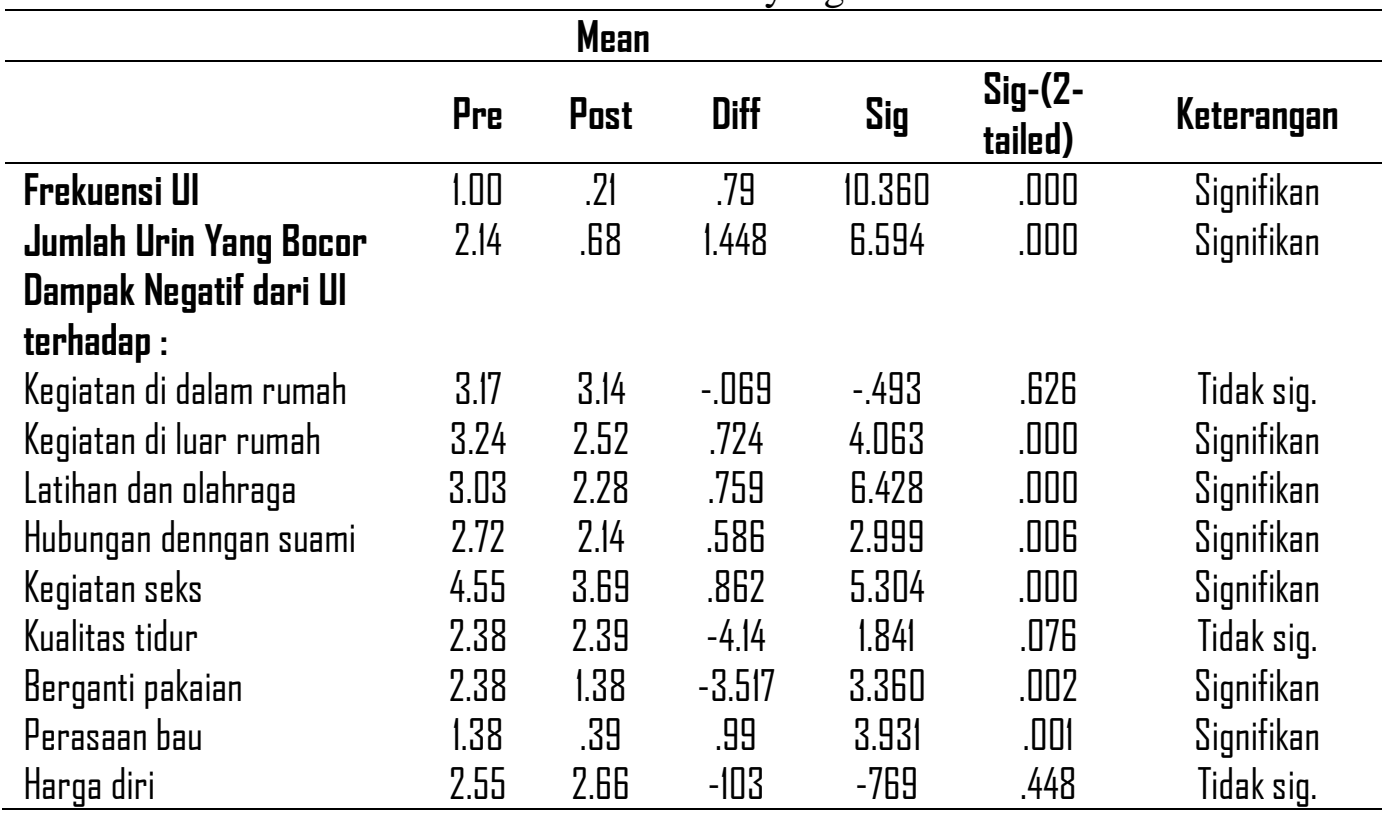

Berdasarkan Tabel 2. dapat dilihat penurunan jumlah urin yang bocor sebelum dan sesudah latihan Kegel

Hasil pretest menunjukkan nilai rerata urine yang bocor adalah adalah 2.14. Hasil posttest menunjukkan penurunan ke angka .68. Pebedaan nilai merata mencapai 1.44. Hal ini menunjukkan bahwa latihan Kegel efektif mengurangi jumlah urine yang bocor dan ini didukung oleh nilai $p \leq .000$.

Pada tabel-2 tampak bahwa latihan Kegel efektif dalam menurunkan beberapa dampak negatif IU seperti 
kegiatan diluar rumah, latihan dan olahraga, hubungan dengan suami, kegiatan seks, berganti pakaian dan perasaan bau dengan nilai signifikan $<.05$. Tabel yang sama juga mengindikasikan bahwa latihan kegel tidak mempengaruhi kegiatan di dalam rumah (nilai signifikan.626 >.05), kualitas tidur (0.76>.05) dan $\mathrm{n}$ harga diri $(.448>.05)$.

Tabel-2 di atas menggambarkan adanya perubahan kualitas hidup para lansia setelah melakukan latihan Kegel. Sebelum latihan Kegel ada 7\% lansia yang mengatakan kualitas hidup mereka buruk tetapi setelah latihan kegel menurun menjadi 0\%. Sebelum intervensi Berdasarkan tabel-tiga bahwa ada $82 \%$ lansia yang menyatakan kualitas hidupnya netral atau tidak baik dan tidak buruk. Setelah latihan Kegel angka ini menurun drastic hingga $31 \%$. Disisi yang lain sebelum latihan kegel hanya sedikit lansia yang memiliki kualitas hidup yang baik yaitu $7 \%$. Setelah latihan kegel meningkat sangat tajam menjadi $67 \%$. Pada kualitas hidup sangat baik tidak terjadi perubahan karena angka 4\% sebelum latihan tetap bertahan $4 \%$ setelah Latihan.

Rerata kualitas hidup lansia sebelum latihan Kegel adalah 3.02 dan setelah latihan Kegel meningkat menjadi 3.72 dengan perbedaan rerata 0.70 . Angka ini menunjukkan adanya perbedaan sebelum dan sesudah latihan Kegel. Nilai signifikasi adalah .000. Hal ini mengindikasikan adanya pengaruh yang signifikan latihan kegel terhadap kualitas.

\section{PEMBAHASAN}

Penelitian ini membuktikan bahwa latihan Kegel efektif menurunkan frekwensi IU dan jumlah urin yang bocor. Dengan demikian penelitian ini mendukung penelitian-penelitian terdahulu. Penelitian yang serupa dengan menggunakan pretest dan posttest design menunjukkan penurunan frekwensi inkontinensia urin pada lansia sebesar $21.6 \%$ setelah melakukan latihan Kegel (Mustofa dan Widyaningsih, 2009). Latihan Kegel secara signifikan terbukti efektif dalam dengan nilai $\mathrm{p} .000$

Dengan metode yang berbeda juga latihan Kegel dinyatakan lebih efektif dibandingkan dengan penggunaan placebo pada grup kontrol. Saat dibandingkan dengan beberapa intervensi menggunakan latihan Kegel, obat Oxybutrin Chloride, dan placebo. Hasil nilai rata-rata adalah penurunan inkontinen $80.7 \%$ pada kelompok latihan Kegel, $68.5 \%$ pada penggunaan obat dan $39.4 \%$ dengan placebo. (Zurcher, Saxer, Schwendimann, 2011; Dumoulin, Hay-Smith. 2010, Burgio, et al, 1998).

Latihan kegel yang dilakukan secara teratur dan berkesinambungan dapat menguatkan otot rangka pada dasar panggul, sehingga memperkuat fungsi sfingter eksternal pada kandung kemih yang memampukan seseorang untuk menahan berkemih. Otot dasar panggul merupakan rangkaian otot dari tulang panggul sampai tulang ekor. Kuatnya otot panggul juga memberikan sokongan pada vulva sehingga memungkinkan pasien untuk terlibat dalam aktivitas seksual yang yang berkualitas. (Nygard, 2010; Widianti \& Proverawati, 2010).

Menurunkan dampak negatif IU adalah menjadi tujuan utama dari manajemen IU. Berkurangnya dampak negatif akan sangat berpengaruh kepada kualitas hidup secara keseluruhan. Hal ini terbukti pada penelitian ini. Meskipun 
hanya sebagian dampak negatif yang berkurang kualitas hidup para lansia terlihat meningkat.

\section{KESIMPULAN}

IU urine merupakan satu permasalahan yang sering dialami oleh para lansia terutama pada wanita. Dampaknya negatif sangat beragam tergantung pada keparahan IU sendiri, kepribadian dari orang tersebut dan tentunya strategi menanganinya. Dampak-dampak negatif tersebut sangat berpengaruh terhadap kualitas hidup secara keseluruhan.

Tujuan utama manajemen inkontinensia tentunya untuk mengurangi frekwensi inkontinensia, jumlah urine yang bocor dan dampak negatif dari IU tersebut. Dampak akhirnya tentunya perbaikan kualitas hidup seperti yang dilakukan oleh Negara Australia yang mengeluarkan dana yang sangat besar untuk para penderita inkontinensia dengan tujuan untuk memfasilitasi penderita agar tetap aktif berpartisipasi di dalam masyarakat

Hasil penelitian ini membuktikan bahwa latihan Kegel efektif dalam mengurangi frekwensi inkontinensia, jumlah urine yang bocor dan beberapa dampak negatif IU dan secara keseluruhan meningkatkan kualitas hidup.

Ada beberapa dampak negatif IU seperti aktifitas di dalam rumah, kualitas tidur, dan harga diri yang tidak terpengaruh oleh latihan Kegel. Disarankan kepada peneliti selanjutnya untuk mengkombinasikan latihan Kegel dengan intervensi lainnya yang dapat menurunkan menangani dampak negatif tersebut secara keseluruhan.

Menimbang keuntungan yang dihasilkan setelah berlatih Kegel maka penulis merekomendasikan latihan ini untuk diterapkan dan dipromosikan kepada para lansia yang mengalami IU, juga kepada yang belum sebagai upaya pencegahan. Latihan ini selain dapat dilakukan di mana saja, kapan saja dan juga tidak memerlukan biaya. Hal-hal yang diperlukan adalah komitmen untuk melakukannya secara teratur dan berkesinambungan.

\section{DAFTAR PUSTAKA}

Association of Women's Health Obstetric and Neo-natal Nurse. (2000). Continence for women. Evidence-based practice guideline. National Guideline Clearinghouse. Retrieved November 5, 2017 from: http://www.guideline.gov/

Australian Institute and Health Welfare. Incontinence in Australia: prevalence, experience, and cost 2009 (20212). Retrieved from https://www.aihw.gov.au/getme dia/ad85fef0-29a0-4343-be20d7c08380bd86/14433.pdf.aspx? inline $=$ true

Barber, M.D., Visco, A.G., Wyman, J., Fantl, J.A., Bump. (2002) Continence Program for Women Research Group. Sexual function in Women with urinary incontinence and pelvic organ prolapse. Am Coll Obstet Gynaecol., 9: 281-9.

Boyle, P., Robertson, C., Mazetta, C., et al. (2014). The prevalence of male urinary incontinence in four centers. In Sumardi R, Mochtar CA, Junizaf, Santoso BI, Setiati S, Nuhoni SA, et al. Prevalence of urinary incontinence, risk factors and its 
impact: Multivariate analysis from Indonesia nationwide survey. Acta Med IndonesIndones J Intern Med., 46:17582 .

Buckley, B.S., Lapitan, M.C.M. (2016) Prevalence of urinary incontinence in men, women, and children - current evidence: findings of the Fourth International Consultation on Incontinence. The Journal of Urology, 76: 265-70.

Burgio, K.L, et al. (1998) Behavioral vs drug treatment for urge urinary incontinence in older women: a randomized controlled trial. JAMA, 280(23):1995-2000

Charalambous, S., Trantafylidis, A. (2009) Impact of urinary incontinence on quality of life. Pelviperineology, 28:51-2.

Dumoulin, C., Hay-Smith, J. (2010) Pelvic floor muscle training versus no treatment, or inactive control treatments, for urinary incontinence in women. Cochrane Data Base System Review, 1:CD005654.

Ge, J., Yang, P., Zhang, Y., (2011) Prevalence and Risk Factors of Urinary Incontinence in Chinese Women: A Population-Based Study. Retrieved November 6, 2017 from http://journals.sagepub.com/doi /abs/10.1177/10105395114293 70?journalCode $=$ apha

Irwin, D.E., Kopp, Z.S., Agatep, B., Milsom, I., Abram, P. (2011) Worldwide prevalence estimates of lower urinary tract symptoms, overactive bladder, urinary incontinence and bladder outlet obstruction. BJU Int.108:1132-8

Kolcaba, K., Dowd, T. (2000) Kegel Exercises Strengthening the weak pelvic floor muscles that cause urinary incontinence. AJN., 100 (11):59

Mustofa, A dan Widyaningsih, W (2009) Pengaruh latihan Kegel Terhadap Frekuensi lnkontinensia Urine Pada Lansia di Panti Wreda Pucang Gading Semarang. Jurnal Keperawatan. 2(2): $42-8$

Meville, J.L., Delaney, K., Newton, K., Katon, W. (2005) Incontinence severity and major depression in incontinence women. Am J Obstet and Gynaecol. 106: 585592.

Milsom, I., Altman, D., Cartwright, R., et al (2013). Epidemiology of urinary incontinence (UI) and other lower urinary tract symptoms (LUTS), pelvic organ prolapses (POP) and anal incontinence (AI). In Abram P, Cardozo L, Khoury S, Wein A, eds. Incontinence. Paris: International Consultation on Incontinence, 15-108

Nilson, M., Lalos, A., Lalos, O. (2009) The impact of female urinary incontinence and urgency on quality of life and partner relationship. Neurol Urodyn, 28: 976-81.

Nojomi, M., Armin, E., Rad, R. (2008) Urinary incontinence: Hospital- 
based prevalence and risk factors. JRMS.13:22-8.

Nugroho, H.W. (2012) Keperawatan Gerontik dan Geriatrik. EGC: Jakarta

Nygaard, I. (2010) Idiopathic urgency urinary incontinence. The New England journal of medicine, 362(12):1156-62.

Potter P.A and Perry, A.G. (1993) Fundamentals of Nursing: Concepts, Process, and Practice. $3^{\text {rd }}$ Ed. St. Louis: Mosby

Shaw C. (2001) A review of the psychosocio predictor of health seeking behavior and impact on quality of life in people with urinary incontinence. Journal of Clinical Nurse, 10:15-24.

Sinclair, A.J., Ramsay, I.N. (2011) Review the Psychosocial Impact of Urinary Incontinence in Women. The Obstetrician and Gynecologist, 13: 143-8.

Subak, L., Richter, H. R, Hunskaar, S. (2009) Obesity and urinary incontinence: epidemiology and clinical research update. The Journal of Urology. 182: S2-S7.
Sumardi, R., Mochtar, C.A., Junizaf, Santoso, B.I, Setiati, S., Nuhoni, S.A., et al. (2014) Prevalence of urinary incontinence, risk factors and its impact: Multivariate analysis from Indonesia nationwide survey. Acta Med Indones-Indones J Intern Med., 46:175-82.

The Canadian Continence Foundation. What is Urinary Incontinence: General Fact: A briefing document. Retrieved November, 2017 from www.canadiancontinence.ca

Thirugnanasothy, S. (2010) Managing urinary incontinence in older people. BMJ, 341:339-43

William, K. (2010) Stress urinary incontinence: treatment and support. Nursing Standard, 18 (31):45.

Zurcher, S., Saxer, S., Schwendimann, R. (2011) Urinary incontinence in Hospitalized Elderly Patients: do nurse recognize and manage the problem? Nursing research and practices. Retrieved November 5, 2017 from:

http://www.ncbi.nlm.nih.gov/p/ $\underline{\text { mc/article/PMC3169375 }}$ 